\title{
"Will They Fight? Ask the Enemy": Iowa's African American Regiment in the Civil War
}

\author{
DAVID BRODNAX SR.
}

SOME FIFTY YEARS AGO Dudley Cornish's groundbreaking book, The Sable Arm, called attention to the extent and importance of the African American military presence in the Civil War. ${ }^{1}$ But with the exception of the famous 54th Massachusetts Infantry, whose service was later dramatized in the film Glory, the nation's individual African American regiments have not, as a rule, attracted much serious historical research. Iowa's African American regiment, the First Iowa Volunteers (African Descent), later redesignated the 60th United States Colored Infantry, has suffered from that general neglect.

The first historian to take note of the regiment was Hubert Wubben, who recorded the existence of the "First Iowa African Infantry," as he termed it, but little more. He wrote only that it was organized in 1863 and that it "saw no combat, but performed guard and garrison duty in St. Louis and in other parts of the lower Mississippi Valley." This brief summation hardly did justice to the regiment's experience, but at least Wubben provided a reference citing official records where materials for

1. Dudley T. Cornish, The Sable Arm: Negro Troops in the Union Army (New York, 1956).

Research for this article was supported by a 2004-2005 State Historical Society of Iowa Research Grant. I am indebted to the State Historical Society of Iowa for its support for this project.

THE ANNALS OF IOWA 66 (Summer/Fall 2007). (C) The State Historical Society of Iowa, 2007. 
a more inclusive account of the regiment could be found. Two years later Ira Berlin and his associates published The Black Military Experience as part of a multivolume document collection on Emancipation. That book made no specific reference to black Iowans in uniform, but it did mention "a recruiting rendezvous at Keokuk, Iowa, just across the Missouri line. Iowa-based recruiting parties scoured northern Missouri and slaves readily enlisted." Robert Dykstra's Bright Radical Star, a comprehensive study of Iowa's antislavery movement and its political wars over racial equality, brought these disparate references together. Dykstra suggested how the Iowa unit's military service influenced the success of the postwar effort to establish black suffrage and other rights. In doing so he constructed a brief account of the regiment's recruitment at Keokuk and St. Louis, its deployment to eastern Arkansas, its valiant participation in the Battle of Wallace's Ferry, and its appalling losses to disease. ${ }^{2}$ This article, building on an intensive search of archival and local materials, offers a more detailed description of Iowa's African American regiment in the Civil War.

WHEN THE WAR BEGAN in 1861 black Iowans were legally barred from voting, holding office, attending public schools, serving in the militia, practicing law, or settling in Iowa at all. Four years later, however, unprecedented steps toward black equality were under way, and almost 300 black Iowans had asserted their right to equal citizenship through service in the state's African American regiment. ${ }^{3}$

Missouri slaves had sought freedom in Iowa since the 1830s, but the war helped drive them north in greater numbers than ever before. ${ }^{4}$ Although some settled in the older African Ameri-

2. Hubert H. Wubben, Civil War Iowa and the Copperhead Movement (Ames, 1980), 130, 250n; Ira Berlin et al., eds., The Black Military Experience (Cambridge, 1982), 188; Robert R. Dykstra, Bright Radical Star: Black Freedom and White Supremacy on the Hawkeye Frontier (Cambridge, MA, 1993), 196-98.

3. Dykstra, Bright Radical Star, 197 and passim. Dykstra notes that 287 men of the regiment (32 percent) listed their residences as Iowa; most of the others were identified as Missourians.

4. Ibid., 90-91, 198-99. 
can communities in Muscatine and Dubuque, most of the newcomers went to Mount Pleasant, Keosauqua, Des Moines, Davenport, villages in the Nodaway River valley, and especially Keokuk. ${ }^{5}$ A variety of factors led to the decisions to settle in those locations, including proximity to the Mississippi River and the Missouri border; the willingness of white racial progressives, especially Congregational and Quaker clergy, to help refugees find jobs, housing, and education; the burgeoning wartime economy in Keokuk and Davenport; and government programs to assist the new arrivals. Jeff Logan, for example, taking advantage of the chaos of war, left central Missouri in 1862 on his master's horse, leading a pair of wagons carrying 12 other fugitives. In Des Moines he worked at a hotel and on a farm before opening his own business. He soon became an unofficial job broker for other newcomers. ${ }^{6}$ Some African Americans went to more isolated agricultural regions, encouraged by white Iowa soldiers to go north and find work as servants or farm laborers. ${ }^{7}$ In all of these new locations, migrants established black churches, schools, and other community institutions. ${ }^{8}$ Most worked as

5. See, for example, Helen Johnson, oral history interview by Kathryn Neal, Marshalltown, 8/26/1998, 3-4, in "Giving Voice to Their Memories: Oral Histories of African-American Women in Iowa," box 1, Iowa Women's Archives, University of Iowa Libraries, Iowa City; and Council Bluffs Daily Bugle, 9/27/1866.

6. The Underground Railroad (Part 3), 108, “The Negro in Iowa," folder 9, box 1, WPA Papers, State Historical Society of Iowa, Iowa City [hereafter cited as SHSI-IC]; The Negro in Des Moines and Polk County, 338, folder 19, box 1, WPA Papers.

7. Nathaniel W. Watkins to Abraham Lincoln, Jackson, MO, 2/22/1863, Abraham Lincoln Papers, Library of Congress, "American Memory from the Library of Congress," http://memory.loc.gov/ammem/alhtml/malhome.html (last accessed 12/20/2006); Kenneth L. Lyftogt, From Blue Mills to Columbia: Cedar Falls and the Civil War (Ames, 1993), 90-91. For more on black migration to Iowa, see Craig R. Klein, Davenport's Pioneer African-American Community: A Sourcebook (Davenport, 2003), master file \#3, 54; and Charline J. Barnes, ed., Life Narratives of African Americans in Iowa (Chicago, 2001).

8. A sample of sources on this topic includes Hazelle Lanman, "African Americans in Keosauqua," in The Keosauqua Experience (1940), Keosauqua Public Library, Keosauqua; Hazel Smith, "The Negro Church in Iowa" (master's thesis, University of Iowa, 1926), 36; "Geraldine Brown: Burlington's Black History," Research Files: Burlington-Geraldine Brown, Research Files: Frances Hawthorne Papers, Iowa Women's Archives; Black Binder, Nodaway Valley Historical Museum [hereafter cited as NVHM], Clarinda; and John Charles Luf- 
general laborers, servants, and washerwomen, or at other lowpaying jobs, but a few entered a middling class of barbers, waiters, and small entrepreneurs. ${ }^{9}$

In 1862 Alexander Clark, a barber and real estate dealer from Muscatine and the state's leading black spokesman, wrote to Governor Samuel Kirkwood offering to raise companies of black troops to join one of the state's all-white regiments. Like many other African Americans, Clark saw the war as a battle over slavery and felt that black Iowans should share some of the burden in fighting it. But Kirkwood's secretary, Nathan Brainerd, cautioned Clark, "You know better than I the prejudices of our people for you have felt them more severely, and you know your color would not be tolerated in one of our regiments. However wrong this may be we cannot ignore the fact." 10

Despite this rebuff, African Americans and their progressive white allies kept pressing, with considerable support coming from the Republican editors of the Davenport Gazette, the Iowa State Register, and the Burlington Hawk-Eye. The Iowa State Register, for example, declared, "Manhood is not necessarily confined to any particular color or race; . . . the poorest and most degraded bondman who offers his services in the defence of the Republic, is better than any white Traitor, North or South, who by ballot or bullet is seeking its overthrow." The Hawk-Eye, arguing that "none can now have the same stake in the contest as the negroes themselves," supported the enlistment of southern

kin, "Black Des Moines: A Study of Select Negro Social Organizations in Des Moines, Iowa, 1890-1930" (M.A. thesis, Iowa State University, 1980).

9. For this subject, see, for example, Moses Mosley's obituary in Mt. Pleasant Free Press, 5/13/1916; Klein, Sourcebook, master file \#3, 97; Ruth Beitz, "Going Up to Glory Very Slow," Iowan 16 (Spring 1968), 45; Sarah Toubes, "Ex-Slave, 102, Recalls the Plantation Lashes and Her Escape to Des Moines," Des Moines Register, 3/18/1925.

10. Dykstra, Bright Radical Star, 196; Hubert H. Wubben, "The Uncertain Trumpet: Iowa Republicans and Black Suffrage, 1860-1868," Annals of Iowa 47 (1984), 413, citing N. H. Brainerd to Alexander Clark, 8/8/1862, Governor's Letterbook, 1861-1863, Kirkwood Correspondence, State Historical Society of Iowa, Des Moines (hereafter cited as SHSI-DM). Although the governor's feelings about Clark's offer are not clear since he did not directly respond to it, in 1862 he was no Radical Republican on racial issues; he supported colonization and believed that the war was for Union and not abolition. Dan Elbert Clark, Samuel Jordan Kirkwood (Iowa City, 1917), 145, 150, 225. 
blacks both on humanitarian grounds and as a useful wartime measure. That argument would ultimately prove compelling to moderates for whom winning the war trumped conservative racial misgivings. 11

Like their counterparts in other northern states, Iowa's political leaders gradually came to favor black enlistments. In the summer of 1863 one local gathering of Republicans declared that they "most heartily endorse the action of the Administration in issuing the Emancipation Proclamation, and in arming and equipping the colored man, and putting him in the field in defence of our country, and believe it to be the heaviest blow that has been struck at the heart of the rebellion." 12 Leaders of both political parties realized that enlisting black soldiers would help fill Iowa's required military quota, thereby exempting white men from the draft. ${ }^{13}$ U.S. Senator James Grimes declared, for example, that he "would see a negro shot down in battle rather than the son of a Dubuquer." 14

Finally, the demonstrated quality of black troops from other states had a strong impact on white Iowans' racial attitudes, especially among soldiers. Although some had been comparatively fair-minded on racial issues before the war, many others were transformed by the conflict itself. ${ }^{15}$ The Battle of Milliken's

11. Iowa State Register, 2/18/1863, quoted in Olynthus B. Clark, The Politics of Iowa during the Civil War and Reconstruction (Iowa City, 1911), 175; Burlington Hawk-Eye, 7/25/1862. See also Burlington Hawk-Eye, 5/12/1862, quoting the Davenport Gazette; and V. Jacque Voegeli, Free but Not Equal: The Midwest and the Negro during the Civil War (Chicago, 1967), 16.

12. This specific language comes from the Jefferson County GOP convention. Clark, The Politics of Iowa during the Civil War and Reconstruction, 166; Burlington Hawk-Eye, 8/22/1863.

13. Charles E. Payne, Josiah Bushnell Grinnell (Iowa City, 1938), 149-50, 161; Russell L. Johnson, "'Volunteer While You May': Manpower Mobilization in Dubuque, Iowa," in Paul A. Cimbala and Randall M. Miller, eds., Union Soldiers and the Northern Home Front (New York, 2002), 42. Joseph Allan Frank, With Ballot and Bayonet: The Political Socialization of American Civil War Soldiers (Athens, GA, 1998), 52, argues that thanks in part to black soldiers, Iowa and every other midwestern state except Wisconsin and Indiana actually did avoid the draft.

14. Voegeli, Free but Not Equal, 102, citing Dubuque Times, 9/28/1862.

15. For example, Lieutenant Benjamin Pearson of the 36th Iowa Infantry, a preacher from Henry County, had numerous positive interactions with African Americans in Arkansas during the war, and even became caretaker for 
Bend, Mississippi, where black Louisiana troops fought alongside the 23rd Iowa Infantry (the only white regiment in the battle), proved particularly important. ${ }^{16}$ Private Samuel H. Glasgow, for example, approvingly wrote to his wife that "I just believe, that they would stand and Fight until the last man was Killed before they would retreat without orders." 17 After learning of such heroic efforts, many white Iowans developed new attitudes - still largely racist, but also appreciative of African Americans' military capabilities. ${ }^{18}$

two black orphans. Even he was not without prejudice, though: he sometimes used words such as darkey and niger quarters and seemed to be most bothered by slavery when it was applied to light-skinned African Americans. "Benjamin F. Pearson's War Diary," Annals of Iowa 15 (1925-27), 83-129, 194-222, 281-305, 377-89, 433-63, 507-35; Donald C. Elder III, ed., Love Amid the Turmoil: The Civil War Letters of William and Mary Vermillion (Iowa City, 2003), 57.

16. Roster and Record of Iowa Soldiers in the War of the Rebellion, Together with Historical Sketches of Volunteer Organizations, 1861-1866, 6 vols. (Des Moines, 1910), 3:680-81. In addition to Milliken's Bend, white Iowans would fight alongside U.S.C.T. regiments at Poison Springs, Jenkins's Ferry, Nashville, Fort Blakely, and Mark's Mills. S. H. M. Byers, Iowa in War Times (Des Moines, 1888), 289-300, 361-66, 410-15.

17. Samuel H. Glasgow to Mrs. Glasgow, Youngs Point, LA, 6/11/1863, Miscellaneous Microfilm (306 Misc), Civil War Letters, Samuel H. Glassgow, Co. F, 23rd Iowa Inf., SHSI-DM. This man is often confused with Samuel L. Glasgow, who led the unit at Milliken's Bend as a lieutenant colonel and was later promoted to full colonel. There were in fact five men named Glasgow in the 23rd Infantry. Roster and Record, vol. 3.

18. One could write an entire article just on the transformed racial attitudes of white Iowa soldiers, but one example will suffice. At the beginning of the war John Mathews of the 13th Iowa had considered "darkies" little more than property; by June 1863 he was a first lieutenant with the 8th Louisiana Colored Infantry (which fought at Milliken's Bend) and though still an unabashed racist was able to praise black soldiers for their bravery. Abstract, John Mathews Letters, 1861-1869, Civil War Letters, Misc., 1863-1893, SHSI-IC; John Mathews to unidentified friend, 12/22/1861, Moreau Bridge, Jefferson City, MO, folder 3, John Mathews Letters; Mathews to parents, 6/15/1863, Milliken's Bend, folder 9, John Mathews Letters. By 1864, he acknowledged that "the colored troops of this command have made a glorious name for themselves, they have proven themselves as brave as the bravest, perfectly at home in the drill, and far ahead of everything else in Military appearance in discipline. . . . You may think me an enthusiastic. But when you pass through what I have with them and seen what I have seen, you will better understand my feelings toward that unfortunate race. . . . There is a better day coming for these poor people." Mathews to Mrs. Vaughan, 11/30/1864, Vicksburg, folder 11, John Mathews Letters. 
That battle also transformed Governor Kirkwood's attitude into a combination of recognition of black bravery, conservative pragmatism, and partisan politics. In a speech in West Union he pointed out that every black soldier killed at Milliken's Bend had saved the life of a white Iowan. He could now "see no objections to their fighting for us if they want to. . . . They themselves gave the answer at Milliken's Bend, where the fortunes of the day turned upon their heroic conduct." 19 Kirkwood also contrasted black sacrifice with Copperhead disloyalty, asking, "Which is the most decent man, the white man who when called upon deserts and skulks away, or the negro who comes up bravely and fights? The man who fights, the man who does what he can to help crush the enemies of the country is the man with whom I would clasp hands always." 20

Some Iowans in the field even began to link martial worthiness to increased political rights. After the Battle of Tupelo, Frederick Humphrey of the 12th Iowa Infantry wrote that black troops "served their country faithfully - have fought like veterans, as they are, and are entitled to their country's gratitude." 21

ON MAY 25, 1863, U.S. Secretary of War Edwin M. Stanton authorized Brigadier General Lorenzo Thomas to organize new regiments by recruiting former slaves in the lower Mississippi Valley. Thomas appointed Colonel William Pile, an ardent abolitionist, to handle the job in Missouri. Both men realized that there were potential soldiers in southern Iowa and asked Kirkwood for permission to recruit there. The governor was not sure there were enough black Iowans to fill an entire regiment (ideally 950 enlisted men plus 50 white officers), but he gave the

19. H. W. Lathrop, The Life and Times of Samuel J. Kirkwood, Iowa's War Governor (Iowa City, 1893), 252, 257-58.

20. Lathrop, The Life and Times of Samuel J. Kirkwood, 259. In Kirkwood's most famous statement about black troops he declared, "When this war is over and we have summed up the entire loss of life it has imposed on the country, I shall not have any regrets if it is found that a part of the dead are niggers and that all are not white men." Kirkwood to Henry W. Halleck, quoted in Ira Berlin et al., eds., Freedom's Soldiers: The Black Military Experience in the Civil War (New York, 1998), 87-88.

21. Ted Genoways and Hugh H. Genoways, eds., A Perfect Picture of Hell: Eyewitness Accounts by Civil War Prisoners from the 12th Iowa (Iowa City, 2001), 225-29. 
project his blessing. War Department General Order No. 122 declared, "Whereas authority has been granted . . . to raise a regiment of men of African descent, and, whereas, the rendezvous of said regiment has been fixed at Keokuk, Iowa . . . the regiment will be known as the First Regiment of Iowa African Infantry." 22

Black leaders such as Alexander Clark and George V. Black, a Washington village barber, began recruiting tirelessly. Black was named a sergeant in the new regiment. Clark, after enlisting 50 men by giving each of them two dollars (according to one story), won appointment as sergeant major, the highest rank available to a black volunteer, but he failed the army's physical exam due to an old leg injury. ${ }^{23}$

The relatively small number of black Iowans occasionally induced military recruiters to use unsavory methods. Former slave Henry Clay Bruce later recalled that agents came to his home in Brunswick, Missouri, more than a hundred miles below the state line, to acquire enlistments on behalf of "certain townships in Iowa, in order to avoid a draft [t]here." When some proved unwilling to go, the recruiters resorted to impressments to fill their quotas. Bruce was "greatly relieved when a company was filled out and left for some point in Iowa." 24

Bruce's recollections may have been colored by his apologist stance toward former slaveholders and his hostile attitude toward Union soldiers, but similar encounters occurred elsewhere. Governor Kirkwood asked Major General John M. Schofield, Union commander in Missouri, to recruit for the Iowa regiment in the eastern part of that state. Schofield agreed that

22. Roster and Record, 5:1585.

23. The Iowa Negro in War, folder 17, box 1, WPA Papers, citing Washington County Press, 12/2/1863; Frances Hawthorne, African Americans in Iowa: A Chronicle of Contributions, 1830-1992 (Des Moines, 1995), 9; Robert V. Morris, "Black Iowans in Defense of the Nation," in Bill Silag et al., eds., Outside In: African-American History in Iowa, 1838-2000 (Des Moines, 2001), 97. In December the Washington County Press lamented that Clark could not serve, asking, "How many white men would do more?" Quoted in The Iowa Negro in War, 311.

24. Henry Clay Bruce, The New Man: Twenty-Nine Years a Slave, Twenty-Nine Years a Free Man (York, PA, 1895), 107-8. 
he could fill several companies in St. Louis, but would not "permit officers to go through the State recruiting in the usual manner, because of the abuses which necessarily result and the consequent disturbance in the country." He was probably referring to complaints by Unionist slaveholders. Missouri was still a slave state, but because it was not classified as "in rebellion against the United States" under the Emancipation Proclamation, that decree did not apply there. Anti-secessionist slaveholders thus protested against their human properties being lost to the army. 25

Instances of morally questionable recruitment also occurred in Iowa itself. In Black Hawk County the local recruiting officer promised George Butler, a 46-year-old black barber, that if he signed on he would receive a $\$ 200$ bounty and could join any Iowa unit he liked. When Butler reported to Camp McClellan in Davenport seeking to join the cavalry, however, he was instead consigned to the black regiment despite his complaints about the trickery. Cedar Falls Gazette editor Henry Perkins denied that the recruiting officer had any part in "drawing the wool over the darkey's eyes." 26

Thanks to the efforts of African American community leaders and Union recruiting officers, seven companies of the new regiment (A through $\mathrm{G}$ ) were mustered in at Keokuk, with the last four recruited at St. Louis. As with all black outfits in Federal service, its commissioned officers were white. Colonel John G. Hudson, previously a captain in the 33rd Missouri Infantry, commanded. Information on Hudson is limited; military records show that he had spent most of the war so far in bloodless

25. J. M. Schofield to Samuel J. Kirkwood, St. Louis, 11/4/1863, in The War of the Rebellion: A Compilation of the Official Records of the Union and Confederate Armies, series 3 (Washington DC, 1899), 1:993; Dykstra, Bright Radical Star, 197. Although there were far fewer black men in Iowa than in southern states, a higher percentage was available for military service because most of them were working for civilians; by contrast, in areas closer to the battlefront many black men had become essential to the war effort as army laborers, and officers sometimes did not want to let them go. In some cases, black men could make more money working for the army as laborers than as soldiers, especially since the monthly salary of ten dollars for black troops was three dollars less than what white soldiers got and did not include a clothing allowance. Berlin et al., eds., The Black Military Experience, 13.

26. Lyftogt, From Blue Mills to Columbia, 113; Roster and Record, 5:1595. 
patrol duty, although he had seen combat in Missouri earlier that year. ${ }^{27}$

Various Iowa county histories published in the late nineteenth century provide information on the other white officers. For men such as New York native Ralph Teller of Lee County, Iowa's African American regiment provided instant promotion; he had enlisted in the Second Iowa Infantry as a private, joined the black regiment as a first lieutenant, and eventually left the service as a captain. ${ }^{28}$ Iram Sawyer of Fayette County got the chance to resume an active role in the military after a year recuperating from a leg wound. ${ }^{29}$

A majority of the regiment's enlisted men, however, were Missourians or recent arrivals from Missouri. ${ }^{30}$ Aside from basic data such as age and place of birth found in military records,

27. Frederick H. Dyer, A Compendium of the War of the Rebellion (New York, 1959), vol. 1. Most of the First's white officers were Iowans, including many from abolitionist towns in southern Iowa. Roster and Record, vol. 5.

28. Portrait and Biographical Album of Lee County, Iowa (Chicago, 1887), 341.

29. Nelson C. Roberts and S. W. Moorhead, Story of Lee County, Iowa, 2 vols. (Chicago, 1914), 2:20, 23.

30. The misconception that most members of the 60th were part of Iowa's prewar population and that nearly every able-bodied black male Iowan had enlisted began only a few years after the war was over. Davenport Gazette, 4/17/ 1867; Byers, Iowa in War Times, 568; Roster and Record, 5:1585. The idea may have started with some creative accounting by Governor Kirkwood in an effort to save white lives. In January 1864 Thomas Vincent of the War Department informed Kirkwood that more than one-third of the soldiers that he had claimed for Iowa would be credited to its southern neighbor. Thomas M. Vincent to Samuel J. Kirkwood, Washington, DC, 1/21/1864, in War of the Rebellion, series 3, 3:41. Official war records credit Iowa with 440 black troops. I searched through the 1860 federal census and a computer database of soldiers from the USCT, crosschecking for names of black Iowan males who were at least 13 years old in 1860 and also served in black regiments. Nine names turned up, although it is possible that others joined the regiment under different names to avoid being identified by their former masters. All but 34 members of the regiment had been born somewhere other than Iowa, although so had most other Iowans. Not surprisingly, most members of the 60th listed Mississippi River towns or southeastern Iowa as their current place of residence, but some came from Iowa City, Des Moines, Newton, and even the faroff southwestern region of the Nodaway Valley. "Civil War Soldiers and Sailors System" (last checked 8/30/2004); History of Van Buren County, 449-50, 453, 455; Theodore M. Cook, Boys in Blue: Van Buren County in the Civil War, 1861-1865 (Bonaparte, 1963), 50, 198; Joseph T. Glatthaar, Forged in Battle: The Civil War Alliance of Black Soldiers and White Officers (New York, 1990), 42; Roster and Record, vol. 5; 1860 U.S. Census. 


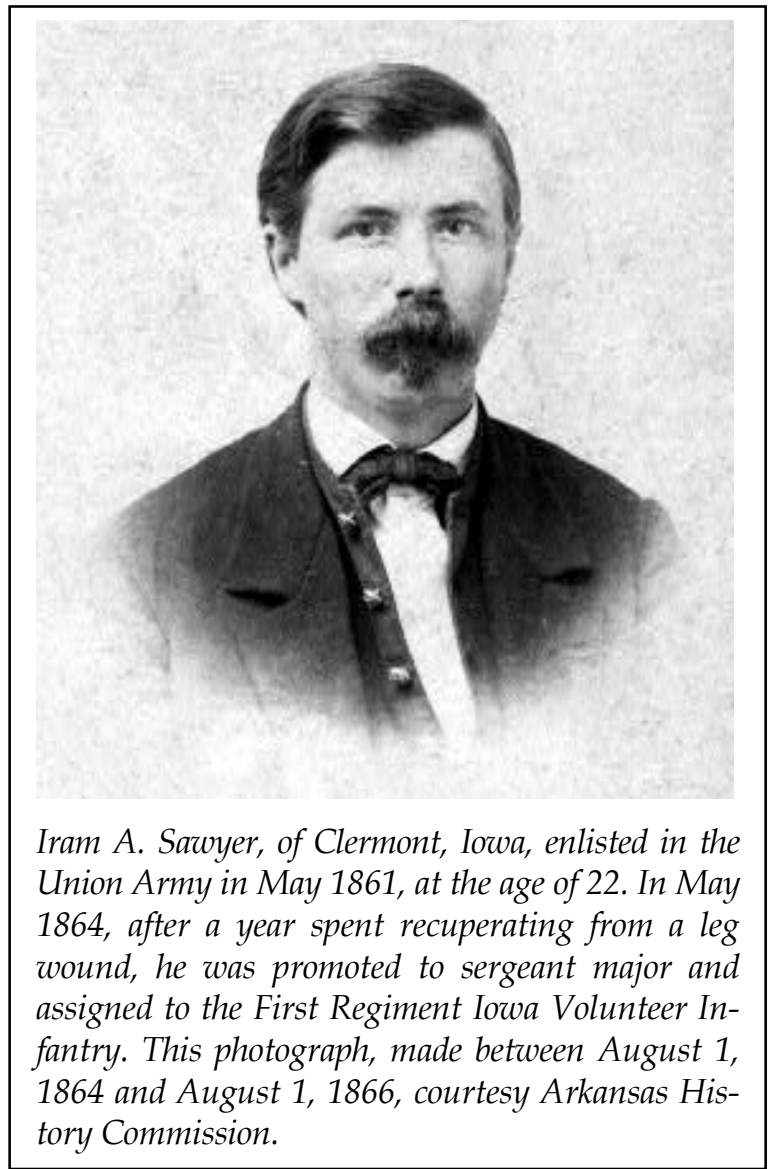

more extensive information for a select few individuals comes from scattered obituaries and news stories. Jason Green had been born free in Madison County, Kentucky. In 1862 or 1863 he made his way to Missouri and then to Newton, Iowa, accompanied by his friends Alexander E. Fine and brothers Taylor, John, and Lewis Mayes. Fine had been working as a plantation overseer, and Lewis was still a slave. After arriving in their new home, Jason and Lewis worked for white families and attended the local country school, despite the objections of some parents. All enlisted in the late summer of 1863 . Three served as privates, but Taylor qualified as a musician and John (the only one of the five who did not survive the war), was named a ser- 
geant. These black Newtonians were joined by fugitive slaves Clem Miller, who had lived in town since leaving Savannah, Missouri, in 1855, and Walker Waldon, who had left Virginia in 1862, possibly joining Jason Green's family along the way. ${ }^{31}$

Another private, described but not identified in a newspaper account, had been a slave in St. Louis. His mother lived in Davenport, and her fellow parishioners at a predominantly white Episcopal church collected $\$ 900$ to buy his freedom. The grateful young man briefly attended school in Davenport before enlisting. ${ }^{32}$ Before the war Milton Howard had been kidnapped from Muscatine as a child and sold into slavery in northern Alabama. During the war he escaped and returned to Iowa, this time settling in Davenport. He enlisted in January 1864, giving his age as 19 although he was probably much younger. (Howard may have been the only trilingual African American in Iowa: he had reportedly learned French from his master and in Davenport studied German with the German family that took him in.) ${ }^{33}$

The most extensive chronicle of any black enlisted man appeared in a 1923 article in the Annals of Iowa. John Graves and his friends Alex Nichols, Anderson Hayes, and Henderson Hayes were all Kentucky natives who had been taken to Nodaway County, Missouri, as slaves before the war. After Northern troops invaded, the four men learned that their masters were planning to send them south to Texas, so they made plans of their own, "borrowing" four horses and mules and heading for Canada, which they thought was relatively close. Despite having to travel at night and hide during the day, they reached central Iowa within the week. The provisions of the Fugitive Slave Law still required the rendition of escaped slaves, tempting some whites to win monetary rewards from grateful southern owners.

31. Newton Journal, 6/21/1899, 6/22/1899; Newton Daily News, 12/9/1919, $10 / 11 / 1913$. Waldon was so closely linked with Newton's other black veterans that Alexander Fine's obituary mistakenly included him in a list of former Missouri slaves. Newton Daily News, 12/9/1919.

32. August Richter, "Davenport Purchased a Slave," August Richter Papers, box 2-Newspaper Clippings: Negroes, SHSI-IC.

33. Rock Island Daily Argus, 8/8/1875. Morris, "Black Iowans in Defense of the Nation," 95, contends that Howard joined the First African as a drummer boy, but the Roster and Record, 5:1628, lists his rank as private. See also Davenport Democrat, 4/18/1915. 
One such group captured Graves's party in Winterset while they were waiting for their horses to be shod. Their captors could find no police officers willing to jail the fugitives, so they formed a ring around them and "dared anyone to try to come inside." Sympathetic townspeople eventually rushed the cordon, helped the fugitives escape, and fed them before giving them directions to Newton, where all of them found work as farm laborers until they enlisted. Graves took his employer's last name and signed up as John Sherer. After the war he brought his parents and three sisters up from Missouri. His father had changed the family name to Miller, so his son did the same and became John Ross Miller. ${ }^{34}$

THE SIX IOWA COMPANIES mustered at Keokuk were sworn into service in on October 11, 1863, and joined the four strictly Missouri companies a month later at St. Louis. After another month of drilling at nearby Benton Barracks, the entire regiment headed south to Arkansas on December 14. ${ }^{35}$ For the next two years it would be stationed in or near Helena, an important Mississippi River town. Although Arkansas was largely out of the conventional war by 1863, guerilla fighting continued to cause instability and destroyed what had been a flourishing antebellum economy. Helena itself was secure, but bands of Confederate bushwhackers roved through the nearby countryside. ${ }^{36}$

Iowa's African American regiment found the "alien and undesirable" landscape around Helena to be the temporary home of some 20,000 white troops (including two Iowa regiments), a thousand other black troops, and several thousand black refu-

34. C. C. Stiles, "John Ross Miller," Annals of Iowa 19 (1934), 384-86; G. Galin Berrier, "The Story of One 'Colored' Infantryman," Des Moines Sunday Register, 5/19/2002.

35. Thirteen men died in Keokuk, and 22 more at Benton Barracks. Janet B. Hewett, ed., Supplement to the Official Records of the Union and Confederate Armies, Part 2, Record of Events, vol. 78, Serial No. 90 (Wilmington, NC, 1998), 345-46, 357.

36. Roster and Record, 5:1586; Thomas A. DeBlack, With Fire and Sword: Arkansas, 1861-1874 (Fayetteville, AR, 2003), 35; Michael B. Dougan, Confederate Arkansas: The People and Policies of a Frontier State in Wartime (University, AL, 1976); Daniel E. Sutherland, "Guerillas: The Real War in Arkansas," in Anne J. Bailey and Daniel E. Sutherland, eds., Civil War Arkansas: Beyond Battles and Leaders (Fayetteville, AR, 2000), 133-54. 


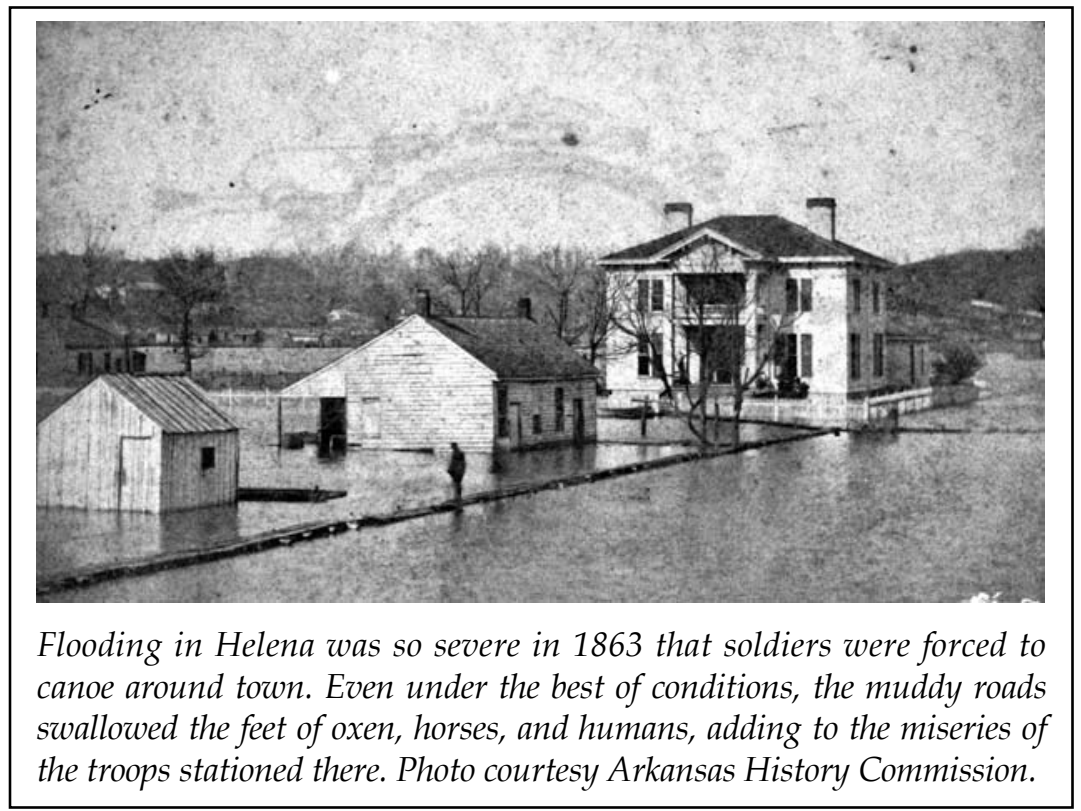

gees. ${ }^{37}$ With its extremes of weather, its muddy streets, its lack of fresh produce, and its sanitation problems, the town was so unhealthy that the soldiers nicknamed it "Hell-in-Arkansas." 38 According to Nurse Margaret E. Breckinridge,

You never saw so wretched a place as Helena; low damp, and enveloped in a continual fog, the rain poured down the whole time we were there, and the camps stretching for miles up and down the river looked like the constant and abiding dwelling-place of fever and ague, and it is without doubt a most sickly post, and why it is held still though known and proved to be a most unhealthy place, nobody seems able or willing to tell. The mud is enough to frighten anybody who does not wear cavalry boots, and the soldiers, who with all their hardships and privations have

37. War of the Rebellion, series 1, vol. 34, part 4-Correspondence, 608; Thomas A. DeBlack, "1863: 'We Must Stand or Fall Alone,'” in Mark K. Christ, ed., Rugged and Sublime: The Civil War in Arkansas (Fayetteville, AR, 1994), 75, 78; Howard C. Westwood, Black Troops, White Commanders, and Freedmen during the Civil War (Carbondale, IL, 1992), 167-79.

38. DeBlack, "1863," 75; Andrew F. Sperry, History of the 33d Iowa Infantry Volunteer Regiment, 1863-6 (Des Moines, 1866), 14; Barry Popchock, ed., Soldier Boy: The Civil War Letters of Charles O. Musser, 29th Iowa (Iowa City, 1995), 21. 
a joke for everything, tell grave stories of mules and wagons being lost forever in the streets of Helena, two pointed ears being the self-erected monuments to tell where each mule is buried. ${ }^{39}$

Although disease was the war's greatest killer for soldiers of all races, black troops died in much higher percentages due to their harsher working conditions, inferior rations and supplies, and poor medical care. Conditions at the Helena hospital for African Americans proved to be some of the worst in the nation. Within a week of the regiment's arrival, an officer reported that "the sick list is increasing daily." One of the first to die was George Butler, the Cedar Falls barber who had wanted to be a cavalryman. Eventually more than 300 others would share his fate. ${ }^{40}$

The only advantage to military life in Helena was its safety from attack, thanks to a series of surrounding hills and ravines, four well-armed batteries, the earthworks at Fort Curtis on the west edge of town, and the guns of the steamer U.S.S. Tyler tied up at the river bank. ${ }^{41}$ But that also meant that many soldiers in Helena suffered from tedium, with little fighting to do, and they drilled constantly just to alleviate the boredom. ${ }^{42}$

To keep up morale, Iowa's troops may have borrowed for their anthem the "Marching Song of the First Arkansas," written by that regiment's commander to the tune of "John Brown's Body." Although there is no evidence that the Iowa troops sang

39. Orr Kelly and Mary Davies Kelly, Dream's End: Two Iowa Brothers in the Civil War (New York, 1998), 34-36. In January 1864, 20-25 men from the 36th Infantry fell sick each day, many from a strain of diarrhea nicknamed the "Tennessee Quick-Step." Ibid., 49.

40. Lyftogt, From Blue Mills to Columbia, 113. Disease killed 90 members of the First African in January-March, 1864. Roster and Record, vol. 5.

41. William Vermillion of the 36th Iowa considered it "impossible for a rebel army to get in here." Elder, Love Amid the Turmoil, 123. When 7,000 Confederates attacked on July 4,1863, the Federal troops inflicted 1,636 casualties and suffered only 239. DeBlack, "1863," 78-79, 85, 102-3; Byers, Iowa in War Times, 236-37.

42. Sperry, History of the 33d Iowa, 31. The soldiers' lot was still better than that of the black civilians-described as "wretched, uncared for, sad-looking creatures" - who had even less shelter, clothing, and food as well as vindictive former masters. Kelly and Kelly, Dream's End, 35. See also DeBlack, With Fire and Sword, 87; and Lyftogt, From Blue Mills to Columbia, 90-91, citing Cedar Rapids Gazette, 6/12/1863. 
this song, it would have been a simple matter to alter its opening line from the "First of Ar-kan-saw" to the "First of I-o-wah," giving the troops a striking, historically informed boost of racial pride and militancy.

Oh, we're the bully soldiers of the 'First of Iowa,'

We are fighting for the Union, we are fighting for the law,

We can hit a Rebel further than a white man ever saw,

As we go marching on....

We have done with hoeing cotton, we have done with hoeing corn, We are colored Yankee soldiers, now, as sure as you are born; When the masters hear us yelling, they'll think it's Gabriel's horn, As we go marching on. ${ }^{43}$

The regiment's spirits were undoubtedly further boosted by a regimental banner, sewn by African American women in Muscatine and Keokuk. ${ }^{44}$ The unit's élan encouraged local African Americans to enlist. Over the next two years the regiment would take in more than a dozen new men from Helena. ${ }^{45}$

During the first six months of 1864, the unit performed garrison duty, scouted in the nearby countryside and Mississippi islands, and performed fatigue duty-unloading supply ships, driving teams, and building fortifications. On January 29, for example, Iowa Companies A through D remained in camp while Company E was protecting government wood choppers on Island No. 66 and Company F (along with the St. Louis companies $\mathrm{G}$ through $\mathrm{K}$ ) relieved a white Missouri regiment at

43. DeBlack, With Fire and Sword, 87-88. Although the author was probably referring to the biblical Gabriel, his troops could also have had in mind the eponymous Virginia blacksmith who in 1800 had tried to take up arms against slavery, just as they were doing now. See James Sidbury, Ploughshares into Swords: Race, Rebellion, and Identity in Gabriel's Virginia, 1730-1810 (New York, 1997).

44. Morris, "Black Iowans in Defense of the Nation," 97; The Iowa Negro in War, 312. Other black Iowans on the home front supported the war effort in various ways: Alexander Clark opened a barbershop for soldiers at Muscatine's Camp Strong, and black clergy prayed for the troops. John J. Witmer, “Thomas C. Motts: In a Quiet, Peaceable and Orderly Manner," Heritage Reflections (1981), 12; Keokuk Gate City, 5/2/1863.

45. Gregory J. W. Urwin, “'We Cannot Treat Negroes . . as Prisoners of War': Racial Atrocities and Reprisals in Civil War Arkansas," in Bailey and Sutherland, eds., Civil War Arkansas, 220-21; Roster and Record, vol. 5. 


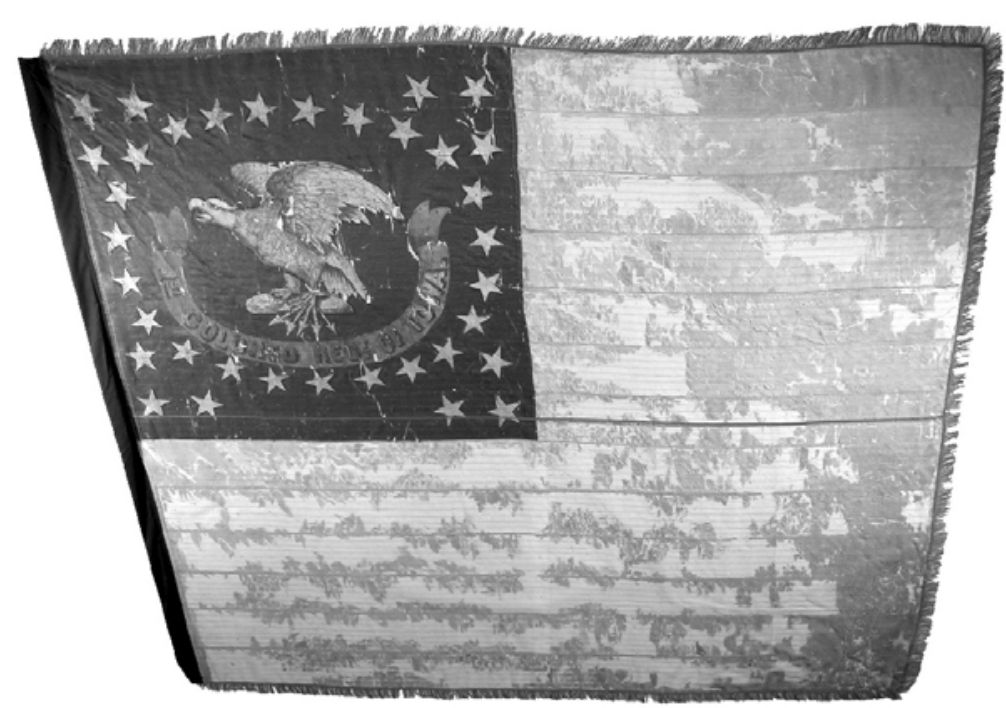

The battle flag of the First Colored Regiment of Iowa is held in the Battle Flag Collection, State Historical Society of Iowa, Des Moines.

garrison duty, engaged in artillery drill, and built and repaired batteries and rifle pits. Although Company K's Missourians quickly became "very efficient in artillery drill," the men of Iowa Company F were kept so busy repairing entrenchments and loading and unloading goods for the quartermaster that its "military efficiency" suffered until it began artillery training toward the end of the month. Company G garrisoned Battery C in January 1864 and remained there for the rest of the year, performing "strong and substantial work." 46

Nearly all the troops scouted the countryside and along the Mississippi, White, and Saint Francis rivers, detaining suspected Confederate sympathizers without suffering any casualties. On January 27 the entire regiment served as part of an "African Guard." In February and early March Companies A, B, and D went on four scouting missions with a company of cavalry nearly 200 miles by steamboat. On one such trip they captured 25 rebels. When nearly all of the Federal black regiments were

46. This was typical of black regiments in Arkansas. See Carl Moneyhon, "1865: 'A State of Perfect Anarchy,'” in Christ, ed., Rugged and Sublime, 149. 
renamed in March 1864, the First Iowa Volunteers (African Descent) became the 60 th U. S. Colored Infantry. ${ }^{47}$

In July Company D reported to Fort Curtis, where it made repairs and drilled with small arms and heavy artillery. One report stated that the men had "made fair progress in the acquirement of knowledge and exhibit a soldierly bearing and efficiency far exceeding the expectations of all experienced observers." An officer praised the men of Company E for their "desire [to] acquire a proficiency in drill, both in artillery and infantry, that marks them as good soldiers." 48

Although the regiment still had not yet seen combat, by the summer of 1864 disease among the troops had become so severe that on any given day only half were available for duty. 49 Conditions had also deteriorated for civilians in the region. Industry had come to a halt, while inflation and guerilla attacks on supply lines made it difficult to buy goods. Corn rotted on the stalk because there was no one to harvest it, and meat was in short supply after an outbreak of hog cholera. ${ }^{50}$

Then, in late July, for the first time in months, the threat of attack surfaced. Confederate General Joseph Shelby and Colonel A. S. Dobbin hatched a plan to mount a major raid against Helena's outlying Unionist plantations. Besides disrupting the cotton economy, such a raid would also, it was hoped, help lay the groundwork for a massive invasion of Missouri later that year. Rebel guerillas near Helena were already intercepting boats, selling captured African Americans back into slavery, and forcing the Union army to build forts staffed by black convalescents. By the end of June 1864 Federal commander Napoleon Buford was worried that the rebels would attack Helena itself, which by then was defended almost exclusively by African Americans, whom he did not trust. He thus requested more

47. Hewett, Supplement to the Official Records, 78:346-52, 356, 361-68; War of the Rebellion, series 3, 4:164-65.

48. Hewett, Supplement to the Official Records, 78:346-47, 352, 356, 364.

49. N. B. Buford to W. D. Green, Helena, 5/6/1864, in The War of the Rebellion, series 3, 1:481-82.

50. Daniel H. Sutherland, "1864: 'A Strange, Wild Time,' " in Christ, ed., Rugged and Sublime, 127; Moneyhon, "A State of Perfect Anarchy," 151; Dougan, Confederate Arkansas, 106. 
white troops. It would not be long, however, before the 60th regiment would prove that request unnecessary. 51

In an effort to "ascertain the force and design of the enemy," Buford sent Colonel William Brooks of the 56th U.S. Colored Infantry and Major Eagleton Carmichael of the 15th Illinois Cavalry on a reconnaissance mission down the Mississippi. Part of Brooks's force consisted of a detachment of the Second U.S. Colored Light Artillery and Iowa Companies C and F of the 60th, both commanded by Captain Eli Ramsey and both under strength. ${ }^{52}$ The total expedition consisted of about 360 men.

The column reached Simms's Ford at Big Creek at about 4 a.m. on July 26 with no sign of Confederates. Carmichael's cavalry crossed the creek and headed west. Soon they found an empty rebel camp and captured several stragglers. Brooks's men crossed the same creek at Wallace's Ferry, but doubled back when his men learned from local African Americans that rebel troops had been in the area only the day before. Shortly after Brooks's men returned to the ferry at about 6 a.m., some 1,500 Confederates led by Colonel Dobbin emerged from the woods only 150 yards away, blocking the road back to Helena. Brooks sent men forward to protect his supply wagons, but Confederate fire forced them back. Dobbin then concentrated on the Federal front and right flank, firing "with vigor." Miles away, Major Carmichael heard the sounds of battle and turned his mounted column back toward the creek. But at Wallace's Ferry the rebels singled out the white officers. Colonel Brooks fell dead, as did a captain, the detachment's surgeon, and the

51. Charles G. Williams, "The Action at Wallace's Ferry, Big Creek, Arkansas, July 26, 1864," Phillips County Historical Quarterly 25 (1987), 46; Captain W. J. McArthur to Col. A. S. Dobbin, Augusta, AR, 7/6/1864, in The War of the Rebellion, series 1, vol. 41, part 2-Correspondence, Etc., p. 994; Buford to Green, Helena, 5/6/1864, ibid., vol. 34, part 3, p. 481; Sutherland, “Guerillas,” 139.

52. Brooks also had orders to acquire cattle or horses belonging to "disloyal persons," to scout Big Creek for a suitable location for a fort and brigade, and to "capture any citizens who have been aiding in conscripting for or furnishing the rebel army," including eight men listed by name. Buford to Colonel W.S. Brooks, Helena, 7/25/1864, in The War of the Rebellion, series 1, vol. 41, part 2, p. 384; Reports of Brig. Gen. Napoleon B. Buford, U.S. Army, Commanding the District of Eastern Arkansas, Helena, 7/26/1864, ibid., part 1-Reports, p. 16; Report of Maj. Eagleton Carmichael, Fifteenth Illinois Cavalry, Helena, 7/27/1864, ibid., part 2, p. 20; Hewett, Supplement to the Official Records, 78:347. 
60th's adjutant. Major Moses Reed of the 56th assumed command. He ordered the men to take cover behind a railroad embankment while canister fire from his artillery, supported by 16 men from the 60th, prevented the rebels from advancing further. The situation might have been worse if not for the fact that the Iowans carried state-of-the-art Enfield rifles rather than the outdated weapons usually issued to garrison troops. The Confederate advance turned into a stalemate until 10 a.m., when the 15th Illinois Cavalry arrived. Dobbin had brought up his reserve and was preparing to make a final assault on the Federal position, but Major Carmichael's cavalry charge disrupted the attack. The rebels turned their attention to defending themselves against the cavalry, but were forced to draw back. ${ }^{53}$

Still, the Federal troops remained greatly outnumbered, and another rebel force of 4,000-6,000 was only an hour away. The two Union commanders, Carmichael and Reed, decided that their best option was retreat to Helena. They abandoned all but two of the heavy guns; with most of the horses dead or wounded, it would have been impossible to transport them all. With the rebels harassing them on all sides, they executed a "gallant and successful" withdrawal, alternating between skirmishing and marching while they carried the wounded and protected the artillery. With eleven miles still to go, the Union detachment found itself confronted with another Confederate force blocking the road, but the Northerners won the advantage, killing seven rebels and dispersing the rest. The Confederates withdrew, and the rest of the retreat to Helena went without incident.

The Battle of Wallace's Ferry ended with an estimated 150 Confederate casualties as against Federal losses of 20 dead, 40 wounded, and 4 missing. For its part, the 60th lost one officer (its adjutant) and 3 privates killed, plus 10 wounded. Three soldiers had been too badly wounded to move from the battlefield and had to be left behind to be executed by the rebels. As elsewhere

53. This and the following paragraph are based on Report of Major General F. Steele, U.S. Army, Commanding the Department of Arkansas, 8/15/1864, in The War of the Rebellion, series 1, vol. 41, part 1, p. 13; Reports of Brig. Gen. Napoleon B. Buford, U.S. Army, Commanding the District of Eastern Arkansas, 7/26/1864, ibid., p. 16; Report of Maj. Eagleton Carmichael, Fifteenth Illinois Cavalry, 7/27/1864, ibid., p. 20. 
during the war, Colonel Dobbin's Confederates did not take black prisoners. For the African American soldiers at Wallace's Ferry and on the trek back to Helena, maintaining discipline and avoiding capture were literally matters of life and death. ${ }^{54}$

Although the "skirmish" at Wallace's Ferry was unimportant in comparison to bloodbaths such as Antietam and Gettysburg, it could have had greater consequence if the Confederates had been victorious. ${ }^{55}$ Intelligence gathered from prisoners revealed that Dobbin's recent attacks on the Helena plantations were meant to draw the Federal troops into the countryside, where a Northern defeat would have given the rebels a chance to take the town itself. ${ }^{56}$ Had Helena fallen, the Confederates would have regained a base to support the planned invasion of Missouri. ${ }^{57}$ It would be a wild exaggeration to suggest that 300 African American troops in eastern Arkansas changed the course of the war, but control of the Mississippi at Helena was an essential part of the Federal strategy in the West, and the action at Wallace's Ferry helped to maintain that control.58

What made the successful venture even more remarkable was that the troops who won the battle had little or no combat experience up to that point. Aside from several skirmishes fought by the 56th, none of the African American troops at Wallace's Ferry had ever heard a shot fired in battle, as military officers noted in the many reports submitted after the battle. One observed that "this was the 'first time under fire' but not a man flinched or failed to do his duty at any time," and First Lieutenant Harmon T. Chappel of the artillery declared,

54. Report of Major General F. Steele; Dyer's Compendium, 2:685; Dykstra, Bright Radical Star, 197; Williams, "The Action at Wallace's Ferry," 48-50.

55. Dyer's Compendium, 2:654, gives the battle this classification.

56. General Buford himself declared that the Union victory had saved his garrison in Helena. Buford to Maj. Gen. C. C. Washburn, 7/26/1864, Helena, AR, in The War of the Rebellion, series 1, vol. 41, part 1, p. 17.

57. By the summer of 1864, some Confederate military leaders were convinced that "the people of Missouri are ready for a general uprising" and it would only take a strong rebel military invasion to inspire them. Sterling Price to Texas Governor T. C. Reynolds, Camden, AR, 7/22/1864, and General Joseph O. Shelby to Lieut. Col. J. F. Belton, Camden, AR, 7/27/1864, in The War of the Rebellion, series 1, vol. 41, part 2, pp. 1020, 1027-28.

58. Christ, ed., Rugged and Sublime. 
During the whole fight the colored men stood up to their duty like veterans, and it was owing to their strong arms and cool heads, backed by fearless daring, alone that I was able to get away either of my guns. They marched eighteen miles at once, fought five hours, against three to one, and were as eager at the end as at the beginning for the fight. Never did men, under such circumstances, show greater pluck or daring. ${ }^{59}$

General Buford also reported that "the colored troops fought like veterans, none flinched," reflecting "great credit" on the 60th. General T. C. Meatyard focused on the fallen white officers, but he also rejoiced "in the glory acquired on this well disputed field by our colored troops. Will they fight? Ask the enemy." 60

After Wallace's Ferry, the 60th returned to uneventful scouting, garrison, and fatigue duty. In August, 80 men traveled to Kent's Landing to retrieve a rebel soldier and two deserters from another unit; they also discovered that two to three hundred Confederates were planning to smuggle guns and ammunition into Arkansas, but heavy rain and poor roads prevented them from intervening. ${ }^{61}$ Three more expeditions in the area around Wallace's Ferry that fall resulted in the capture of ten rebels, the burning of 65 Confederate-held buildings, and the 60th's first combat since the showdown at the ferry. While foraging for cattle at Alligator Bayou in September, they came across six rebels, exchanged fire, and killed two of them. In January 1865 fifty soldiers and a dozen white troops ventured out to recover some stolen horses and to capture a black de-

59. Hewett, Supplement to the Official Records, 78:362; "Report of Lieut. Harmon T. Chappel."

60. "Reports of Brig. Gen. Napoleon B. Buford"; Assistant Adjutant-General T. C. Meatyard, General Orders No. 47, District of Eastern Arkansas, 7/31/1864, in The War of the Rebellion, series 1, vol. 41, part 1, p. 18. For a more flamboyant account of the battle, see Morris, "Black Iowans in Defense of the Nation," 98. For his part, Confederate General Shelby claimed a "brilliant victory" where he "met, fought, and routed completely 1,250 white men and negroes" who were saved from "annihilation" only by the cavalry. Shelby to Belton, Hdqrs. Confederate Forces Northern Arkansas, 7/31/1864, in The War of the Rebellion, series 1, vol. 41, part 1, p. 27.

61. Report of Capt. Eli Ramsey, Sixtieth U.S. Colored Troops, Helena, 8/14/1864, ibid., Part 2, 242-43; Dyer's Compendium, 3:1733. 
serter. They brought back 200 bushels of corn the fugitive had harvested together with an interracial group of refugees. 62

By that time some members of the unit, despite insufficient rations and almost daily scouting, guard duty, fatigue work, and drilling, had learned to read and write, as had many members of other black Union regiments. ${ }^{63}$ There was discontent within the ranks, however; seven men deserted in January, and two white officers were court-martialed and dismissed. 64

On March 21 the 60th was reassigned to Little Rock. They were in the capital when Lee surrendered three weeks later. Like most black regiments, the 60th was now part of an occupation army. ${ }^{65}$ During the summer and early fall they traveled to various locations around northern Arkansas, including Jacksonport and Batesville, until the 709 survivors were mustered out at Duvall's Bluff on October 15. ${ }^{66}$

\section{THE MOST IMPORTANT POSTWAR GOAL for African} Americans all across the North was securing the right to vote, which in Iowa required amending the state constitution through joint resolutions by two consecutive legislative sessions and then a voters' referendum. That process began in the summer of 1865 when Iowa's Republican leaders endorsed black male suffrage. Although the Democrats renamed themselves the Union Anti-

62. Report of Col. John G. Hudson, Sixtieth U.S. Colored Troops, Helena, 9/4/ 1864, in The War of the Rebellion, series 1, vol. 41, part 2, pp. 302-3; Hewett, Supplement to the Official Records, 78:347; Dyer's Compendium, 3:1733; Report of Lieut. Alexander F. Rice, Sixtieth U.S. Colored Troops, Helena, 9/15/1864, in The War of the Rebellion, series 1, vol. 41, part 1, p. 759; Report of Lieut. Alexander F. Rice, Sixtieth U.S. Colored Troops, Helena, 9/29/1864, ibid., part 2, p. 816; Reports of Capt. Eli Ramsey, Sixtieth U.S. Colored Troops, Helena, 1/14/ 1865, ibid., vol. 48, part 1-Reports, Correspondence, Etc., p. 34. Dyer's Compendium, 3:1733, states that Harbert's Plantation was in Mississippi.

63. Steven Hahn, A Nation under Our Feet: Black Political Struggles in the Rural South from Slavery to the Great Migration (Cambridge, MA, 2003), 98, citing the Christian Recorder, 12/31/1864; Hewett, Supplement to the Official Records, vol. 78:347, 350, 352-53, 357-58, 360.

64. Buford to Maj. Gen. J. J. Reynolds, Helena, 3/3/1865, in The War of the Rebellion, series 1, vol. 48, part 1, p. 1067.

65. Hewett, Supplement to the Official Records, 78:348-49, 355, 358, 361, 366, 368.

66. Available information about their activities during this period is less detailed. See Dyer's Compendium, 3:1733. 
Negro Suffrage Party and preyed on Iowans' racial prejudice, the Republican Party swept the statewide elections that fall. 67

The members of the 60th U.S. Colored Infantry performed one last task before dispersing back into civilian life. On October 31, 1865, they held a "Convention of Colored Iowa Soldiers" at Davenport's Camp McClellan to add their collective voice to the movement for suffrage reform. Their "address to the people of Iowa" asserted that "he who is worthy to be trusted with the musket can and ought to be trusted with the ballot." 68 Governor William Stone agreed that the African Americans in uniform had "nobly earned the rights of manhood at the price of valor and blood," and the state legislature passed the necessary joint resolutions in 1866 and 1868. ${ }^{69}$

Iowa's black spokesmen also ensured that the contributions of their soldiery continued to be honored. A convention at Des Moines in February 1868 brought together some 30 black delegates from around the state, in addition to a number of state officials and legislators. After offering an inspiring speech, Alexander Clark read the convention's appeal to Iowa's white voters. It demanded black enfranchisement "in the honored name of [the Civil War's] 200,000 colored troops, five hundred of whom were from our own Iowa." Several Republican newspapers published the document, and it also circulated in pamphlet form. ${ }^{70}$

In the November 1868 election, Iowa's voters gave the Republican presidential candidate, Ulysses S. Grant, 62 percent of the vote. Grant had urged Iowans to vote yes on black suffrage, and most did so; the referendum passed with 57 percent of the vote. ${ }^{71}$ Iowa thus became the only Northern state where voters

67. Robert R. Dykstra, “The Issue Squarely Met: Toward an Explanation of Iowa's Racial Attitudes, 1865-1868," Annals of Iowa 47 (1984), 442-44; Wubben, "Uncertain Trumpet," 444, 419-21.

68. Davenport Daily Gazette, 11/2/1865; Muscatine Journal, 11/6/1865.

69. Stone, "Second Inaugural," in Benjamin F. Shambaugh, ed., Messages and Proclamations of the Governors of Iowa, 7 vols. (Iowa City, 1903-5), 3:80-81, 8485, 89; 1866 Laws of Iowa, 22, 61-62, 106, 163, 166, 173, 277-78.

70. Proceedings of the Iowa State Colored Convention, Held in the City of Des Moines, Wednesday and Thursday, February 12th and 13th, 1868 (Muscatine, 1868), 2-6, 11; Ruth A. Gallaher, “A Colored Convention,” Palimpsest 2 (1921), 178-80.

71. G. Galin Berrier, "The Negro Suffrage Issue in Iowa, 1865-1868," Annals of Iowa 39 (1963), 258-60. 
elected to extend suffrage rights to black men. ${ }^{72}$ At one of the many Republican celebrations around the state, barber William Davis, an ex-slave and army veteran, addressed an interracial audience in Albia on what freedom meant to black Iowans. ${ }^{73}$

IN THE YEARS TO COME the 60th's white officers probably had little contact with the men who had served under them. ${ }^{74}$ Information on the postwar lives of black soldiers is as limited as their prewar histories. But occasional obituaries and local histories are helpful. Former private Lindsay Pitts "made and lost a small fortune" owning and operating several saloons, a barbershop, and a billiard room in Davenport. ${ }^{75}$ John Ross Miller worked as a janitor at a Des Moines museum and bought property in both the capital and in Newton. ${ }^{76}$ George Black returned

72. Many other northern states debated the issue after the war, including five in 1868 alone, but in the five years between the war and the ratification of the Fifteenth Amendment, black suffrage was rejected in 14 northern states and the District of Columbia. The only victories were in Iowa, Wisconsin, and Minnesota, and Wisconsin's took place through a court decision, while Minnesota's snuck in through the back door via a suffrage referendum that made no direct reference to race. Thus Iowa was, in Robert Dykstra's words, "the only straightforward victory for Negro suffrage." Robert R. Dykstra and Harlan Hahn, "Northern Voters and Negro Suffrage: The Case of Iowa, 1868," Public Opinion Quarterly 32 (1968), 202-5; Wubben, "The Uncertain Trumpet," 410.

73. Frank Hickenlooper, An Illustrated History of Monroe County, Iowa (Albia, 1896), 183.

74. More information about the 60th's white officers can be found in the sources following their names, listed below, in addition to the other biographical sources listed in previous footnotes. Captain Gardiner A. A. Deane and Captain Ralph Teller: Portrait and Biographical Album of Lee County, Iowa (Chicago, 1887), 341-42. Second Lieutenant William Henry Williams: Memorials of Deceased Companions of the Commandery of the State of Illinois, Military Order of the Loyal Legion of the United States, from January 1, 1912 to December 31, 1922 (Chicago, 1923), 300-301. Dr. Anderson Patton had the only recorded interaction with an enlisted man from the 60th after the war. After returning to his medical practice in Nevada, Iowa, he was visited one day by Private Oscar Blue, who had traveled from Missouri to get Patton's assistance in applying for a government pension; Patton did not remember the accidental wound that Blue had suffered during the war until he saw the man in person but then immediately signed an affidavit allowing the former enlisted man to get his pension. Glathaar, Forged in Battle, 262.

75. The Iowa Negro in War, 314; "Colored Political Leader Succumbs," Davenport Democrat and Leader, 12/31/1913; Klein, A Sourcebook, master file \#3, 83.

76. Stiles, "John Ross Miller," 384. 


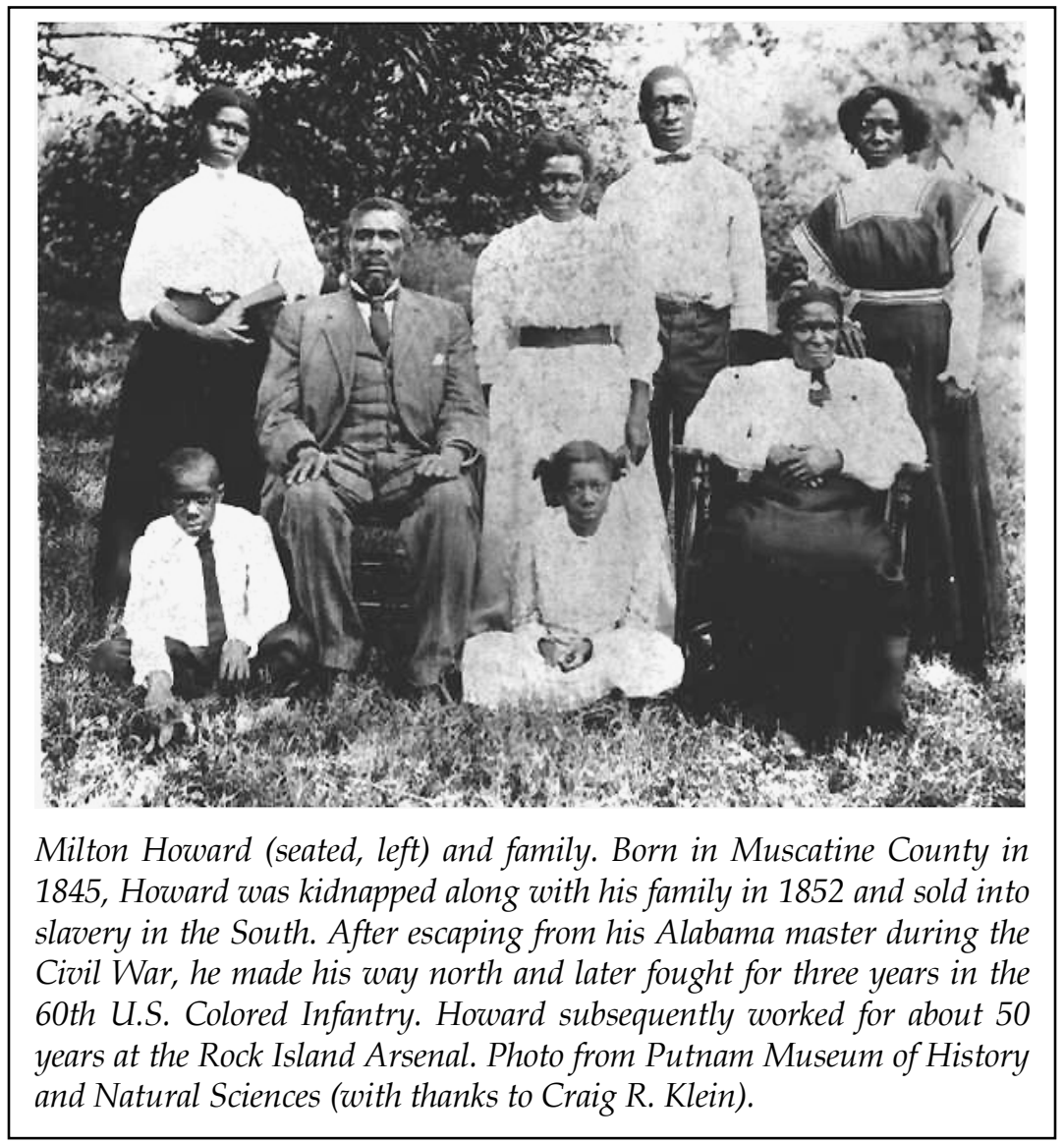

to Washington, Iowa, and served as an officer in several State Colored Conventions. ${ }^{77}$

The most curious story belongs to Milton Howard. He worked at the Rock Island Arsenal for 50 years and earned notoriety for crawling over the thin ice of the Mississippi River to save a prominent white citizen one winter. The deeply religious Howard never uttered a stronger oath than "God darn it!" and refused to strike another man with his hands, which he believed were "so destructive that they were lethal." Late in life he tried building an airplane, believing that God had told him to "be

77. Muscatine Daily Journal, 1/8/1869. 
prepared for the heavenly flight on judgment day." He worked on the plane for six years until his money ran out, continuing to believe that "I still have that vision in my head and if no one will help me to build my ship, I will keep it there until judgment day." When he died in 1928, the Grand Army of the Republic gave him full burial rites. ${ }^{78}$

None of the men of the 60th lived long enough to witness the civil rights victories of the twentieth century, but they had helped set the stage for those breakthroughs by participating in the movement for political equality in Iowa. In the long run, their contribution to reform proved more historically significant than anything that the 60th U.S. Colored Infantry did on the battlefield. Even so, the mere existence of an African American regiment from a state with such a small black population remains an important part of Iowa's Civil War record.

78. Davenport Daily Times, 3/19/1928; Davenport Democrat, 4/18/1915; Hope D. Williams, An Oral History of the Black Population of Davenport, Iowa (Davenport, 1979), interview 4:5-6. 